\title{
The Advocates' Obligations to Swear According to Their Religion or Promise at the High Court Open Session in the Perspective of Independence of the Advocate Organization
}

\author{
Erry Meta, Made Warka, Hufron \\ 1. Doctorate of Law Candidate at Law Faculty of 17 Agustus 1945 University of Surabaya, Surabaya, Indonesia \\ 2.Lecturer of Faculty of Law, 17 Agustus 1945 University of Surabaya, Surabaya, Indonesia \\ 3.Lecturer of Faculty of Law, 17 Agustus 1945 University of Surabaya, Surabaya, Indonesia
}

\begin{abstract}
This study discusses two-issue namely (1) Ratio legis advocates must take an oath or promise according to their religion in ; (2) The concept of an advocate's obligation to swear or promise according to religion in the perspective of independence of the Advocate Organization. The two problem formulations were analyzed using normative legal research methods using statute approach, philosophy approach, conceptual approach, comparative approach and case approach. The ratio legis of advocates is obliged to swear or promise according to their religion in an open session of the High Court in their jurisdiction if historical history has traced the adoption of provisions regarding the oath of an advocate as regulated in Article 187 RO (Reglement Of De Regterlijk Organisatie En Her Beleid Der Justitie in Nederlan Indie) which states: "Before receiving their services, lawyers must take the following oath (promise) in an open court at the high court where they are appointed", without being given a legal reason at the time of the formulation of Article 4 paragraph (1) of the Advocate Law, giving attributive authority to the High Court. carry out an advocate's oath / pledge. The legislative ratio of an advocate is obliged to swear or promise according to his religion, in essence, the validity/legality, morality and religiosity of an advocate in carrying out his professional duties, both outside the trial and in the trial.Based on the theoretical basis, the concept of an advocate's obligation to swear or promise according to religion in the perspective of independence of advocate organizations is more appropriately carried out or organized by the advocate organization itself, provided that the advocate in question has taken a special education for the advocate profession correctly, has passed an advocate professional exam organized by the advocate organization according to the standards set and the appointment of an advocate is carried out by the advocate organization selectively and strictly.
\end{abstract}

Keywords: The obligation, Advocate, Promise, Open session High Court, Independence.

DOI: $10.7176 / \mathrm{JLPG} / 109-03$

Publication date:May $31^{\text {st }} 2021$

\section{Introduction}

The birth of Law number 18 of 2003 about advocate (advocate law) is to create a constitutional law country and a justice law enforcement process, so there is no discrimination of law to access justice. The rule and regulation of nomination should be completed as one of the main requirements to be an advocate. The nomination of advocates will be done after the prospective advocates completed all the requirements, they are nominated by the organization however they cannot perform their professional duties right away. They should take an oath according to their religion in an open session of the High Court in their jurisdiction, as regulated in article 4 paragraph (1) and (2) of the Advocate Law that defines “.....before receiving their services, advocates are obligated to take an oath according to their religion or pledged in an open court at the high court where they are appointed."

Philosophically the oath-taking of a prospective advocate by the High Court is to protect the honour of advocate itself, as the importance of advocate inauguration is considered by the Constitutional Court of Indonesia in the verdict number 103/PUUXI/2013, dated 11 September 2011, which stated "... nomination and inauguration of an advocate is a form of improving the quality of advocate who does a noble profession (officium nobile), that in the end, the advocates can build justice in the middle of the society on the law enforcement process in the future in Indonesia...", so the provision listed in Article 4 paragraph (1) of Advocate Law is constitutional.

Advocates' obligation to take an oath according to their religion or to pledge in the open session of the High Court in their jurisdiction before receiving their service at this time is still relevant in the perspective of advocate independence. In the context and perspective of advocate organization independence, the pledge of an advocate is not enough to be done by the organization, as the pledge of police force's member which held in front of a superior official appointed and prosecutor's member in front of chief prosecutor appointed.

This case is related to the provision of Article 5 paragraph (1) of Advocate Law, which stated: "The status of Advocate as a law enforcer, free and independent guaranteed by the law and rules and regulations". It is 
spirited and in tune with the preamble considering the letter $\mathrm{C}$ of Advocate Law, that: "Advocate as a free, independent and responsible profession in law enforcement, should be assured and protected by law for the sake of the implementation of law supremacy enforcement effort." According to the preamble considering Letter (c) and Article 5 paragraph (1) Advocate Law, on the one hand, an advocate is a free, independent and responsible profession, but on the other hand before doing their duty advocates are obligated to take an oath in the open session of High Court in their jurisdiction within the scope of the general court. The existence of this promise for advocates in front of the open session of the High Court before doing their profession can be understood as a part of monitoring the advocate profession.

Normatively, the obligation of taking an oath for advocates which is arranged in Article 4 paragraph (1) of Advocate Law that stated: "Before running the profession, Advocates are obligated to take an oath according to their religion or pledged in the open session of High Court in their jurisdiction" on the one hand, and on the other hand based on the provision Article 5 paragraph (1) Advocate Law stated: "Advocates as a law enforcer, free and independent as assured by law and rules and regulation." Substantively there is norm conflict between both positive law provisions.

Sociological problem on the occasion of advocates' oath or pledge in front of the open session of High Court in the situation of advocates' organization in a de facto manner has the quality of multibar association, bring up many advocates' organizations as long as there is a decree from Ministry of Law and Human Rights, filing a petition to the High Court to hold advocates' oath or promise, without selection process and advocates' nomination based on the provision by Advocate Law.

If traced historically, the provision of oath-taking for advocates should be in the open session of High Court in their jurisdiction is the continuance of the valid provision before the birth of Advocate Law, which is done by the High Court as regulated in Article 187 R.O (Reglement Of De Regterlijk Organisatie En Her Beleid Der Justitie in Nederlan Indie) which stated:

"De advocaten en procureurs moeten, alvorens hunne bediening te aanvaarden, in handen van den president, in eene openbare teregtzitting van het collegie, waarbij zij zijn aangesteld, afleggen den navolgenden eed (belofte).

If traced further in the Treatise of Advocate Law Formulation, particularly related to processing and formulation of Article 4 paragraph (1) the legal ground of why the oath-taking for advocates held in the open session of High Court cannot be found, as if it is (taken for granted) formulated without any legal reason or ratio legis of the election of the authorized High Court to hold advocates' oath-taking or promise. Even if it is tracked and traced on the provision of Advocates' Promise in Netherland at this time, which also held in an open court session of the District High Court where they lived.

Moreover, it is seen as important and interesting to be examined academically in the form of dissertation research which relates to ratio legis that advocates are obligated to take an oath or pledged according to their religion in the open session of the High Court in their jurisdiction and the obligation concept of advocates taking an oath/pledge according to their religion in the perspective of advocate organization independency as ius constituendum.

\subsection{Formulation of the problem}

Based on the background of study above, it is formulated that there are two main dissertation problems as follows: (1) Ratio legis advocates are obligated to take the oath or promise according to their religion in the open session of High Court in their jurisdiction, (2) the obligation concept of advocates taking an oath or promise according to their religion in the perspective of advocate organization independency.

\subsection{The Purpose of the research}

The purposes in this dissertation research are: (1) To analyze and find ratio legis advocates obligatory to take an oath or pledge according to their religion in the open session of High Court in their jurisdiction, (2) To analyze and find the concept of advocates obligatory to take an oath or pledge according to their religion in the perspective of advocate organization independency.

\subsection{Research Method and Approach}

In this research, the juridical normative method is used. It is a method focusing on examining the implementation of principles and positive law norms. Whereas, the approach used in this dissertation are statute approach, philosophy approach, conceptual approach, comparative approach and case approach.

\section{Analysis and Result}

2.1. Ratio Legis advocates must take an oath or promise according to their religion in an open court session of the High Court in their jurisdiction.

The authority given by Article 4 paragraph (1) of Advocate Law to the High Court from general court to run or 
hold advocates' promise in the presence of open session in advocates' jurisdiction, before they receive their duty theoretically including attributive authority. It means the delegated authority to the High Court is given by the advocate lawmaker to have the authority to do advocates' oath-taking is genuine. ${ }^{1}$ Another term of attributive authority is a genuine authority or an authority that cannot be shared with anyone else or an authority that attributed to a position. $^{2}$

According to J.G. Brouwer and A.E. Schilder, attributive authority:

Attribution, power is granted to an administrative authority by an independent legislative body. The power is initial (originair), which is to say that is not derived from previously existing power. The legislative body creates independent and previously non-existent powers and assigns them to authority. ${ }^{3}$

Borrowing J.G. Brouwer and A.E. Schilder's opinion, it is related to the High Court authority to take advocates' oath or promise. It is a genuine authority given to the High Court by The House of Representatives of the Republic of Indonesia, which is not taken from the previous authority or previously is not regulated in law and regulation in the Constitution. In this case, the legislative body creates an independent authority and not an expansion of the previous authority and handed to the High Court straightaway to hold advocates' oath-taking or promise.

If it is related to the characteristic of attributive authority as stated by Suwoto Mulyosudarmo on subchapter of a theoretical base there are two: (1) the formation of attributive authority, creates a new authority, (2) the formation of authority in an attributive manner should be done by an organization which based on rules and regulation (authorized organs). ${ }^{4}$ So, High Court's authority held advocates' oath-taking or promise creates a new authority which does not exist before and the formation is based on rules and regulation (authorized organs) is in Article 4 paragraph (1) of Advocate Law.

Furthermore, considering that the High Court get a direct authority from the norms in Article 4 paragraph (1) of Advocate Law, so the responsibility of authority implementation which fully attributed is on High Court as the recipient of attributive authority (atributaris). ${ }^{5}$

If it is traced further, historically High Court in the scope of the general court that in charge of making an oath or promise of advocates is adopted on the provision of advocates' promise which regulated in Article 187 RO (Reglement of De Regterlijk Organisatie En Her Beleid Der Justitie in Nederlan Indie) in the Dutch EastIndies era.

"De advocaten en procureurs moeten, alvorens hunne bediening te aanvaarden, in handen van den president, in eene openbare teregtzitting van het collegie, waarbij zij zijn aangesteld, afleggen den navolgenden eed (belofte).

Where the existence of this oath or promise, if related to the theory of incorporation group which believe that moral principle is a requirement of law norm validity. ${ }^{6}$ Thereby, it can be said that advocates' oath or promise aimed as the provision of Article 4 paragraph (1) and (2) of Advocate Law is the validity or legality of an advocate to start their duty to give their services, inside and outside the session court.

Furthermore, in connection with advocates' oath or promise if it is connected with Ronal Dworkin's theory of law morality in the good regulation system, which is the law as integrity. Three values strongly related to law as integrity, are fairness, justice, and procedural due process. Fairness is the principles that related to the appreciation of people's rights that should be filled by lawmaker through their representative in the parliament. The value of justice is emphasized more on the quality of the final result from adjudication. As an example, the protection of individual rights and freedom considered by the public as fundamental justice principles, so each verdict that is made by the judge should protect individual rights and freedom in the most morally acceptable way. In the context of advocates' oath or promise, fairness and justice values will do the duty to give their law service in an honest, fair and responsible manner based on law and justice.

Procedural due process value demanded to respect the law procedures, when deciding new rules and when the law is implied on particular or concrete cases. This value is related to the principle of legal security. ${ }^{7}$ In the context of advocates' oath or promise, will not refuse to provide assistance or law service in a case which is a part of the professional responsibility of an advocate, including to watch their behaviour and responsibility under their honour, value and responsibility as an advocate.

According to Dworkin, the law is not only about rules. In Law, is found inside law principles. These principles are an inseparable part of the law. The reading of these principles, cannot use legalistic reading, it needs moral reading. The most explicit example of these principles is the law basis or general principles in the

\footnotetext{
${ }^{1}$ Ronald Saija, Dimensi Hukum Pengadaan Barang/Jasa, Deepublish, Sleman. 2019. page74.

${ }^{2}$ Ronald Saija, Dimensi Hukum Pengadaan Barang/Jasa, Deepublish, Sleman. 2019. page74.

${ }^{3}$ J.G. Brouwer dan Schilder, ASurvey of Dutch Administrative Law, Ars Aeguilibri, Nijmegen, 1998, page. 16-17

${ }^{4}$ S.F. Marbun, Hukum Administrasi Negara I, FH UII Press, Yogyakarta, page 70

${ }^{5}$ Aminuddin Ilmar, Hukum Tata Pemerintahan. Prenada, Jakarta , 2016. page 116.

${ }^{6}$ Matthew Kramer, Where Law and Morallity Meet, Oxford University Press, 2004, page 2-4.

${ }^{7}$ Khudzaifah Dimyati, dkk., Hukum \& Moral, Basis Epistemologi Paradigma Rasional H.L.A. Hart, Genta Publishing, Yogyakarta, 2017, page. 52 .
} 
constitution. For an instance, "someone cannot get an advantage from the mistake he/she has caused," "everyone has the right to justice law," "everyone deserves a healthy environment," "to the same will be given the same, to the unequal will be given unequally," "Do a good thing, getaway of an evil act," and so on. ${ }^{1}$ In the context of advocates' oath/promise, the legal principles are covering the entire content of an advocates' oath or promise, which are: upholding and practising Pancasila as the basis of the state and the Constitution of Republic Indonesia; carrying out professional duties as a legal service provider and will act honestly, fairly and responsibly based on law and justice; carrying out professional duties inside and outside court by not giving or promising anything to the judges, court officials, as well as other officials or, will maintain their behaviour and responsibility under their honour, dignity and responsibility as advocates; as in other legal values and principles, that will not refuse to defend or provide legal services in a case according to their belief is a part of the professional responsibility as advocates.

Apropos of advocates' oath or promise in terms of H.L.A Hart's theory on the relation of law and morals, Hart acknowledged that law, justice and morals are closely related. The connection between law and morality by explaining the relation between law and justice. The general concept related to justice is fairness. A decision is usually referred to as just and unjust by using fair or unfair criteria. ${ }^{2}$ In the context of advocates' oath or promise, the fair criteria are to perform their professional duties as a legal service provider who acts honestly, fairly and responsibly based on law and justice.

As explained above, that profession's pledge which is done by advocates is a promise which is said to give resoluteness in carrying out their profession according to their task and function, so they will not perform their task and function in a deviant and blamable manner. The pledge's text contained moral aspects that should be upheld as a form of personality to support advocates' performance spiritually and physically.

As the findings of the dissertation, it is suggested that ratio legis formulated advocates' oath or promise in philosophical perspective is supposed to be validity base or legality, morality and religiosity of advocates before performing their professional duties, giving law service, inside or outside the court.

Philosophically, advocates oath or promise is a form of improving the quality of advocates' profession who have a noble profession (officium nobile), which in the end advocates can build justice in the middle of the society as their role of law enforcement process in Indonesia.

From the first analysis in the perspective of Authority and Independence Theory, the following results are obtained: Based on the theoretical basis, the comparison of the oath or promise of members of the police force and prosecutor's office, as well as the mandate of the formation of Advocate Law in the consideration of letter (b), in writer's opinion in the context of advocate organization's independence, advocate oath or promise can be done or held by advocate organization itself, with a provision that the advocate involved has completed advocate professional education and passed the professional advocate exam organized by advocate organization according to the standards fixed and the nomination of advocates by the organization should be selective and strict.

\subsection{The concept of an advocate's obligation to swear or promise according to religion in the perspective of independence of the Advocate Organization.}

In connection with independence theory, according to Jimly Ashiddiqie, it can be divided into three: (1) Structural independence, is institutional independence, it can be seen from the organization chart separated from other organizations such as executive and legislative. (2) Functional independence is independence from the collateral implementation of judiciary functions from extra juridical intervention. (3) Financial independence is the independence of determining their financial budget, which assured their independence in performing their duty and function. ${ }^{3}$

In the context of advocate's organization in Indonesia, has completed the requirements of independence as uttered by Jimly Asshiddiqie. First, structural independence is institutional independence, which means in terms of institutional structure, advocate organization is separated from any other institutions, including instructing and supervising by the Government (Ministry of Law and Human Rights) and Supreme Court. Second, functional independence, is independency in performing the functions of advocate organization, including independence in the implementation of functions of advocate organization covering 8 (eight) authorities: a) performing advocate professional education [Article 2 paragraph (1)]; b) performing a test for advocate candidates [Article 3 paragraph (1) letter f]; c) performing advocate nomination [Article 2 paragraph (2)]; d) creating code of ethics [Article 26 paragraph (1)]; e) forming Council of Honor [Article 27 paragraph (1)]; f) forming supervisory

\footnotetext{
${ }^{1}$ Ibid. page 56

${ }^{2}$ H.L.A. Hart, “The Concept of Law”, second edition (oxford; oxford University press,1994), page 158.

${ }^{3}$ Muchsin, Kekuasaan Kehakiman Pasca Perubahan UUD 1945, pepers submitted as lecture material in the Doctorate of Law Program Untag Surabaya in 2009, in Ahmad Zainal Fanani, Kekuasaan Kehakiman yang Merdeka dan Masa Depan Peradilan Agama, http://www.badilag.net, in Research and Development Center of Law and Justice R\&D of Law and Justice Training of Supreme Court RI, Research Report Assessment of the Position of Judges as State Officials, Bogor: Center for Law and Judiciary Research and Development Agency for Education and Training of Supreme Court RI, page 17.
} 
commission [Article 13 paragraph (1)]; g) performing supervision [Article 12 paragraph (1)]; and h) dismissing Advocate [Article 9 paragraph (1)]. (3) Third, financial independence, is independence from the aspect of determining its budget, both institutionally and personally in carrying out its duties and functions have been fulfilled, since they do not depend on donations, assistances and subsidies from the Government.

Related to the independence theory of judicial power, Amran Suadi divides independence into 4 (four) which are: (1) Substantive independence is independence in checking and deciding a case to maintain rightness and justice based on legal principles. (2) Institutional independence is judiciary independence from the intervention of various states institutions and other government institutions in deciding a case. (3) Internal independence is judiciary independence to regulate the personal interest of the judiciary which covers recruitment, mutation, promotion, remuneration, years of service and retirement. (4) Personal independence is the independence of colleagues, leader and the judiciary itself. ${ }^{1}$ If it is related to advocate organization independence in carrying out their duties which related to the function of judicial power as intended in Article 24 paragraph (3) Constitution (UUD) 1945, based on writer's stand has been fulfilled.

First, substantive independence, in this case, is naturally related to the independence in performing 8 (eight) advocate organization tasks as mandated in Advocate Law. Second, Institutional independence is the independence of advocate organization from the intervention of various state and government institutions in carrying out their professional duties, including coaching and supervising by the Government and Supreme Court. Third, internal independence is advocate organization independency to arrange advocate's personal interest, which are a) performing advocate professional education [Article 2 paragraph (1)]; b) performing a test for advocate candidates [Article 3 paragraph (1) letter f]; c) performing advocate nomination [Article 2 paragraph (2)]; d) forming Council of Honor [Article 27 paragraph (1)]; e) forming supervisory commission [Article 13 paragraph (1)]; f) performing supervision [Article 12 paragraph (1)]; and g) dismissing Advocate [Article 9 paragraph (1)]. Fourth, Personal independence is the independence of the members of the advocate in performing their professional duties from the influence of the committee, colleagues and the leader of the advocate organization itself.

Advocate independence or the organization itself from the beginning has been mandated by Advocate Law formers as stated in the preamble considering letter b, c, of Advocate Law is stated as follows:

a. That the judicial power which is free from all external interference and influence, requires a profession of advocate that is free, independent and responsible, to create a judicature that is honest, fair and has legal certainty for all seeker of justice in upholding the law, truth, justice and human rights;

b. That advocate as a profession that is free, independent and responsible in law enforcement, should be assured and protected by the Constitution for the sake of implementing efforts to uphold the rule of law

In the preamble letter $\mathrm{b}$ of Advocate Law, it is stated that judicial power that is free from any external interference and influence, requires a profession of advocate that is free, independent and responsible, for the implementation of an honest, fair and has legal certainty for all justice seekers in upholding law, truth, justice and human rights.

Starting from the consideration above, the formulated provisions of Article 5 paragraph (1) of Advocate Law: "Advocates as law enforcers are free and independent and are assured by law and legislation".

Based on the theoretical basis, the comparison of oath or promise of the members of the police force and prosecutor's office, the nomination of an advocate in Russia, as well as the mandate of Advocate Law former in the preamble considering letter (b), according to the writer's opinion in the context of advocate organization independence, advocate oath or pledge can be done or held by the organization itself, with the provisions that the advocate in question has already completed his or her advocate professional study fairly, has passed the advocate professional test which organized by advocate organization according to the fixed standards and the nomination of an advocate should be done selectively and strictly.

\section{Conclusion and Suggestion}

Based on the analysis of the discussion chapters, academically conclusions are presented as the answer of the problem filed as follows:

1. Ratio legis advocates are obligated to take an oath or pledge according to their religion in an open court session of the High Court in their jurisdiction if traced historically, it adopted the provision about advocate's promise regulated in Article 187 RO (Reglement Of De Regterlijk Organisatie En Her Beleid Der Justitie in Nederlan Indie) which stated: "Before receiving their services, lawyers are obligated to take an oath in an open court session of the High Court in their jurisdiction," without any legal reasons at the formulation of Article 4 paragraph (1) of Advocate Law, give attributive authority to the High Court to take advocate's oath

\footnotetext{
${ }^{1}$.Amran Suadi, Filsafat Hukum Refleksi Filsafat Pancasila,Hak Asasi Manusia, dan Etika. Prenanada Media Group. Jakarta. 2019. page 316
} 
or promise. Ratio legis advocates obliged to take an oath or pledge according to their religion, in spirit the validity or legality, morality and religiosity of an advocate in performing their professional duties, both inside and outside court.

2. Based on the theoretical basis, the concept of advocate's obligation to swear or promise according to the religion in the perspective of advocate organization independence is more appropriate to be done or held by the organization itself, with the provisions that the advocate in question has already completed his or her advocate professional study fairly, has passed the advocate professional test which organized by advocate organization according to the fixed standards and the nomination of an advocate should be done professionally.

Referring to the description of the conclusion above, it is academically advisable to the honourable:

1. Advocates are required to take an oath or promise in public before carrying out their profession, since an advocate's oath or promise is the basis of validity, morality and religiosity of an advocate in performing his or her professional duties, both inside and outside the court, in performing his or her noble profession (officium nobile), uphold law, truth, justice and human rights.

2. To the Legislative Body to revise Article 4 paragraph (1) of Law Number 18 of 2003 about Advocate, related to the obligation for an advocate to take an oath or promise according to his or her religion is no longer held in an open session of the High Court in their jurisdiction. An advocate's oath or promise can be done within the advocacy organization, just after the advocate in question fulfilled the requirements and the nomination of advocates is done professionally by the advocate organization.

\section{References}

Brouwer J.G. dan Schilder, 1998, ASurvey of Dutch Administrative Law, Ars Aeguilibri, Nijmegen.

Fanani, Ahmad Zainal Kekuasaan Kehakiman yang Merdeka dan Masa Depan Peradilan Agama, http://www.badilag.net, dalam Puslitbang Hukum dan Peradilan Badan Litbang Diklat Kumdil Mahkamah Agung RI, Laporan Penelitian Pengkajian tentang Kedudukan Hakim sebagai Pejabat Negara, Bogor : Puslitbang Hukum dan Peradilan Badan Litbang Diklat Kumdil Mahkarnah Agung RI.

Hadjon,Philipus M., 2008, Pengantar Hukum Administrasi Indonesia, cet. 10, Yogyakarta: Gajah Mada University Press.

Hart, H.L.A., 1994, "The Concept of Law”, Oxford, Oxford University Press.

Ilmar, Aminuddin, 2016, Hukum Tata Pemerintahan. Prenada, Jakarta.

Khudzaifah Dimyati, , 2017, Hukum \& Moral, Basis Epistemologi Paradigma Rasional H.L.A. Hart, Genta Publishing, Yogyakarta.

Kramer, Matthew, 2004, Where Law and Morallity Meet, Oxford University Press.

Marbun, S.F. Hukum Administrasi Negara I, FH UII Press, Yogyakarta.

Muchsin, 2009.Kekuasaan Kehakiman Pasca Perubahan UUD 1945, makalah yang disampaikan sebagai bahan kuliah di Program Doktor Ilmu Hukum Untag Surabaya.

Saija, Ronald, 2019, Dimensi Hukum Pengadaan Barang/Jasa, Deepublish, Sleman.

Suadi, Amran, 2019, Filsafat Hukum Refleksi Filsafat Pancasila,Hak Asasi Manusia, dan Etika. Prenanada Media Group. Jakarta. 